\title{
Performance Study and Analysis of a 300MW High Backpressure Heat Supply Unit Condenser after Retrofit
}

\author{
Xue-tong WANG \\ Shandong Branch \\ Huadian Electric Power Research Institute \\ Jinan, China \\ e-mail:xuetong-wang@chder.com \\ Ang SONG* \\ Shandong Branch \\ Huadian Electric Power Research Institute \\ Jinan, China \\ e-mail:ang-song@chder.com
}

\author{
Yu-feng YAN \\ Shandong Branch \\ Huadian Electric Power Research Institute \\ Jinan, China \\ e-mail:yufeng-yan@chder.com \\ Chuan-ling LIU \\ Shandong Branch \\ Huadian Electric Power Research Institute \\ Jinan, China \\ e-mail:chuanling-liu@chder.com
}

\begin{abstract}
This paper introduces the retrofit of the condenser of a $300 \mathrm{MW}$ high backpressure heating turbine. According to the test data of high and low backpressure situation, we calculated the operation indexes of the condenser at these situation. The condenser terminal temperature difference is both small at high and low backpressure situations, the average condenser terminal temperature difference is $2.09^{\circ} \mathrm{C}$ and $2.74^{\circ} \mathrm{C}$ when it's at high and low backpressure situation, which are both are smaller than the design value. After the retrofit, under the normal backpressure condition, the condenser operation pressure is $4.647 \mathrm{kPa}$ at $319 \mathrm{MW}$ load, the condenser pressure is $4.955 \mathrm{kPa}$ after the circulating water flow rate and inlet temperature correction, and the maximum correction terminal temperature difference is $2.15^{\circ} \mathrm{C}$, which is slightly higher than the design value. The condenser performance is improved obviously after the high backpressure retrofit. After the retrofit, the condenser pressure at $320 \mathrm{MW}$ conditions is $0.475 \mathrm{kPa}$ lower than $300 \mathrm{MW}$. Around the load condition of $270 \mathrm{MW}$, the condenser pressure is $0.416 \mathrm{kPa}$ lower than that before the retrofit.
\end{abstract}

Keywords-steam turbine, high backpressure retrofit, condenser retrofit, circulating water heating, performance research

\section{INTRODUCTION}

In the normal condensing thermal power plant, the exhaust steam is cooled and condensed into water in the condenser, the circulating water is heated and emitted the heat through the cooling tower into the atmosphere which results a loss of cold source. The cold source loss is one of the main factors that causing the low cycle thermal efficiency of the steam turbine unit. High backpressure circulating water heat-supply of steam turbine is such a technology that the steam turbine operates at high backpressure during the heating season, the outlet temperature of circulating water increases because the steam turbine exhaust temperature rises. The circulating water heated by the condenser is pumped into heat-supply network to satisfy the user heating demand, and then returns to condenser to be reheated. High backpressure circulating water heat-supply technology reuses the heat that is formerly released into the atmosphere, which saving heating steam and improving the steam turbine economic performance.

The high backpressure circulating water heat-supply technology for condensing units has been widely used in domestic cities in winter, which is an effective measure to save energy, improve environment and deepen heat and power cogeneration [1-4]. One subcritical 300MW heating unit was carried out high backpressure heating transformation for the heat supply requirements, this unit operates at high backpressure instead of normal backpressure during heating seasons, which result great changes of exhaust steam temperature in low pressure cylinder, and pressure of the condenser at steam side and water side. The long-term safety of the condenser can no longer be guaranteed. Therefore, strengthening transformation and overall optimization of the condenser must be implemented to ensure safety and better economic benefit under the high backpressure condition.

\section{THE TECHNICAL SPECIFICATION OF THE CONDENSER}

The 300MW turbine is the first domestic subcritical unit which is carried out high pressure heating retrofit, this unit is a subcritical extraction condensing turbine set, extracting heating steam from the communicating pipe between the low-pressure cylinder and the medium pressure cylinder, the design rated heating extraction steam flow is $300 \mathrm{t} / \mathrm{h}$. After the high backpressure heating transformation on low pressure cylinder, the original low-pressure $2 \times 7$ grade rotor is replaced by a $2 \times 5$ grade rotor with the original 2 grades moving blades and diaphragms removed before entering the heating season, the exhaust backpressure is increased to $54 \mathrm{kPa}$. After the heating season, the original $2 \times 7$ grade 
moving blades and corresponding diaphragms of low pressure rotor are reinstalled, the low-pressure cylinder recovers to the state that it is before, the turbine restores to the situation and backpressure that before the transformation.

\section{A. The Condenser Technical Specification before Transformation}

The condenser technical specification before the transformation is listed in Table 1.

TABLE 1. THE CONDENSER TECHNICAL SPECIFICATION BEFORE TRANSFORMATION

\begin{tabular}{|c|c|c|c|}
\hline Model & $\mathrm{N}-17000-1$ & Type & $\begin{array}{l}\text { Single shell, symmetric separation, } \\
\text { double flow, surface type }\end{array}$ \\
\hline Cooling surface area & $17000 \mathrm{~m}^{2}$ & $\begin{array}{l}\text { Weight (net weight } \\
\text { operation) }\end{array}$ & $358 \mathrm{t} /$ about $670 \mathrm{t}$ \\
\hline $\begin{array}{l}\text { Maximum design } \\
\text { pressure at water side }\end{array}$ & $0.245 \mathrm{MPa}$ & Design pressure at shell side & $0.098 \mathrm{MPa}$ \\
\hline Design backpressure & $4.9 \mathrm{kPa}$ & Titanium pipe size & $\varphi 25 \times 0.5,0.7 \times 10940 \mathrm{~mm}$ \\
\hline $\begin{array}{l}\text { Design cooling water } \\
\text { temperature }\end{array}$ & $20^{\circ} \mathrm{C}$ & Titanium pipe material & TA2 \\
\hline $\begin{array}{l}\text { Design cooling water } \\
\text { rate }\end{array}$ & $37000 \mathrm{t} / \mathrm{h}$ & $\begin{array}{l}\text { Titanium pipe number in } \\
\text { main condensation zone }\end{array}$ & 19984 \\
\hline $\begin{array}{l}\text { Design cooling water } \\
\text { resistance }\end{array}$ & $58 \mathrm{kPa}$ & $\begin{array}{l}\text { Titanium pipe number in top } \\
\text { and air cooling area }\end{array}$ & 1810 \\
\hline
\end{tabular}

\section{B. The Condenser Technical Specification after the Retrofit}

transformation is listed in Table 1.

The condenser technical specification after the

TABLE 2. THE CONDENSER TECHNICAL SPECIFICATION AFTER TRANSFORMATION

\begin{tabular}{|c|c|c|c|}
\hline Item & Parameter & Item & Parameter \\
\hline Condenser model & $\begin{array}{l}\text { DTP/N-17300-Reinforced, single } \\
\text { shell, double flow, surface }\end{array}$ & $\begin{array}{l}\text { Maximum design circulating water } \\
\text { temperature }\end{array}$ & $\begin{array}{l}33^{\circ} \mathrm{C} \text {, heating season } \\
60^{\circ} \mathrm{C}\end{array}$ \\
\hline $\begin{array}{l}\text { Effective area in air } \\
\text { pumping area }\end{array}$ & $1160 \mathrm{~m}^{2}$ & $\begin{array}{l}\text { Designed circulating water } \\
\text { temperature rise }\end{array}$ & $\begin{array}{l}8.8^{\circ} \mathrm{C} \text {, heating season } \\
27^{\circ} \mathrm{C}\end{array}$ \\
\hline Heat transfer coefficient & $3201.9 \mathrm{~W} /\left(\mathrm{m}^{2} .{ }^{\circ} \mathrm{C}\right)$ & $\begin{array}{l}\text { Terminal temperature difference at } \\
\text { design condition }\end{array}$ & $4.2^{\circ} \mathrm{C}$ \\
\hline $\begin{array}{l}\text { Design of circulating water } \\
\text { flow }\end{array}$ & $37000 \mathrm{t} / \mathrm{h}$, heating period $9700 \mathrm{t} / \mathrm{h}$ & $\begin{array}{l}\text { Guaranteed condensate oxygen } \\
\text { content at condenser outlet }\end{array}$ & $25 \mu \mathrm{g} / 1$ \\
\hline $\begin{array}{l}\text { Design of circulating water } \\
\text { temperature }\end{array}$ & $20^{\circ} \mathrm{C}$, heating period $53^{\circ} \mathrm{C}$ & $\begin{array}{l}\text { Condenser backpressure at TRL } \\
\text { condition of circulating water } \\
\text { temperature } 33^{\circ} \mathrm{C}\end{array}$ & $10.80 \mathrm{kPa}$ \\
\hline
\end{tabular}

After the transformation, the condenser operates under high or low backpressure condition. The condenser working pressure at tube side is still $0.245 \mathrm{MPa}$ at non-heating conditions, the circulating water system works in open cycle, using seawater as cooling water source; at the heating season, the circulating water is backwater from the heating network, the condenser working pressure at tube side increased to $1.0 \mathrm{MPa}$, the condenser inlet and outlet water temperature, low-pressure cylinder exhaust steam temperature and condenser pressure are increased.

In the non-heating season, the unit restores to the situation before transformation due to low-pressure cylinder recovers to the state before transformation, the exhaust steam flow and the exhaust steam enthalpy are also similar to the value that before the transformation, so when the condenser operates at low backpressure state after the transformation, the design backpressure is still $4.9 \mathrm{kPa}$, which is same as the data before transformation. 


\section{THE CONDENSER HIGH BACKPRESSURE TRANSFORMATION AND THE GUARANTEED PERFORMANCE}

\section{A. The Detail and Range of the Condenser Technical Transformation}

In order to adapt the high low-pressure cylinder exhaust temperature, exhaust steam pressure and circulating water pressure of the high backpressure situation, changes from normal pressure to high pressure condition, and great changes in the condenser operation condition, the condenser was carried out holistic strengthening transformation.

1) The original condenser shell and drain water flash tank on side are remained, the condenser shell side plate and the bottom plate is checked and reinforced before installation to ensure the proper connection between the modification components and the original ones; the condenser connects the other related equipment in the same way as that before transformation; the condenser supporting mode remain unchanged; the expansion joint between condenser throat and low-pressure cylinder remain unchanged; keep all the supporting elements and equipment in the throat unchangeable; the original condenser rubber ball cleaning system equipment should be suitable for the condenser after transformation; the original condenser back flushing device is retained unchangeable.

2) All the tube bundles, end tube plate, the middle partition plate, the baffle plate, the water retaining plate, the extraction steam-gas device, the internal connecting piece and so on are totally replaced. All above components was designed on the precondition that the backwater pressure is $0.5 \mathrm{MPa}-0.6 \mathrm{MPa}$ during heating period.

3) The condenser front and back water chamber and it's attachment are modified, the design pressure of the condenser water chamber increased to $1.0 \mathrm{MPa}$ from $0.245 \mathrm{MPa}$ before transformation, taking the requirements into account that the condenser operates under high backpressure during heating period, the condenser front and back water chamber and the flange are all updated, the new condenser water chamber is a curved water chamber to improve its bearing capacity; the tube sheet is replaced as a thick one; circulating water pipeline expansion joint with more high pressure bearing capacity is used to ensure condenser's safe and reliable operation in heating season.

4) Cooling pipe is used titanium welding straight pipe.

5) The tube end plate using $\delta 60(\mathrm{Q} 345-\mathrm{B})+\delta 5(\mathrm{TA} 2)$ titanium clad plate to prevent the potential difference corrosion caused by possible electric potential difference between the titanium cooling tube and the condenser tube plate.

The new condenser tube plate is designed on the base that the water chamber design pressure is $1.0 \mathrm{MPa}$ and the end tube plate is $\delta 60(\mathrm{Q} 345-\mathrm{B})+\delta 5$ (titanium tube) titanium clad plate to ensure the condenser safe and reliable operation in heating period.

6) Expansion joint (no packing material) argon arc welding connection is used as the connection between the titanium cooling water pipe head and end pipe plate.

\section{B. The Condenser Performance Safety Precautions and Guaranteed Performance after Modification}

The following measures are used to improve the condenser performance in terms of thermal design.

1) HEI and the imported Germany Barker Tour condenser design technology are used in the condenser thermodynamic design.

2) Peak type as the most advanced condenser pipe arrangement mode is used as the condenser pipe design of the arrangement way to optimize the arrangement of the tube bundle. The best steam condensation effect is ensured by improving the heat load uniformity among condenser tube bundle.

3) The gas-steam extraction system inside the condenser is reconstructed, using multipoint extraction.

4) Guaranteed performance after condenser retrofit

The condenser high backpressure transformation is designed according to the THA operating condition with normal steam turbine backpressure, the condition check is completed according with normal summer backpressure $11.8 \mathrm{kPa}$ and high backpressure $54 \mathrm{kPa}$ condition in heating period. After the condenser high backpressure transformation, the following performance data is guaranteed during the operation of the steam turbine:

Average condenser backpressure (cooling water temperature $20^{\circ} \mathrm{C}$ ): $4.9 \mathrm{kPa}$;

Condensate super cooling degree: $\leq 0.5^{\circ} \mathrm{C}$;

Condenser average terminal temperature difference: $\leq 4.2^{\circ} \mathrm{C}$;

Condensation oxygen content in the condenser outlet: $\leq 25 \mu \mathrm{g} / \mathrm{L}$

Condenser water resistance: $\leq 62 \mathrm{kPa}$;

Condenser circulating water total tolerance temperature rise: $\leq 10.0^{\circ} \mathrm{C}$.

When the circulating water temperature is $20^{\circ} \mathrm{C}$, the condenser backpressure is $4.90 \mathrm{kPa}$; when the circulating water temperature is $33^{\circ} \mathrm{C}$, the condenser backpressure is $11.80 \mathrm{kPa}$.

After the condenser retrofit, at the designed THA condition, when the circulating water flow is $37000 \mathrm{t} / \mathrm{h}$ and the inlet water temperature is $20^{\circ} \mathrm{C}$, the steam pressure is lower than $4.9 \mathrm{kPa}$; under the rated heating condition, the exhaust steam flow is $485 \mathrm{t} / \mathrm{h}$, exhaust steam enthalpy is $2614.7 \mathrm{~kJ} / \mathrm{kg}$, circulating water flow is $9700 \mathrm{t} / \mathrm{h}$, exhaust steam pressure is $54 \mathrm{kpa}$, the heating network circulating water temperature will not less than $80^{\circ} \mathrm{C}$.

\section{THE HIGH AND LOW BACKPRESSURE OPERATIONAL EXPERIMENTAL RESULT AFTER THE CONDENSER RETROFIT}

After the high backpressure retrofit of the steam turbine and the condenser, the condenser operates under the high backpressure condition in the heating period and operates under the low backpressure condition in the non-heating period. In order to understand the condenser running situation and performance in high and low backpressure, experiments are implemented under high backpressure heating condition and low backpressure condensing 
condition with the low pressure cylinder re-equipped with blades. Condenser performance parameters are calculated in two conditions and are compared with those pre-retrofit design value and condenser performance parameters, the results are shown in Table 3.

TABLE 3. THE EXPERIMENT RESULTS OF 300MW UNIT CONDENSER UNDER HIGH AND LOW BACKPRESSURE

\begin{tabular}{|c|c|c|c|c|c|c|}
\hline Parameters & Unit & $\begin{array}{c}\text { High } \\
\text { backpressure } \\
\text { 230MW } \\
\text { condition }\end{array}$ & $\begin{array}{c}\text { High } \\
\text { backpressure } \\
\text { 180MW } \\
\text { condition }\end{array}$ & $\begin{array}{c}\text { Low } \\
\text { backpressure } \\
\text { 320MW } \\
\text { condition }\end{array}$ & $\begin{array}{c}\text { Low } \\
\text { backpressure } \\
270 \mathrm{MW} \\
\text { condition }\end{array}$ & $\begin{array}{c}\text { Low } \\
\text { backpressure } \\
\text { 200MW } \\
\text { condition }\end{array}$ \\
\hline Generator power & $\mathrm{kW}$ & 230432.3 & 179595.4 & 319004.2 & 269718.3 & 210368.6 \\
\hline Main steam flow & $\mathrm{kg} / \mathrm{h}$ & 873705.4 & 657709.7 & 1039099 & 874070.8 & 667366.3 \\
\hline $\begin{array}{l}\text { Condenser inlet water } \\
\text { temperature }\end{array}$ & ${ }^{\circ} \mathrm{C}$ & 51.855 & 48.086 & 19.155 & 20.077 & 20.523 \\
\hline $\begin{array}{l}\text { Condenser outlet water } \\
\text { temperature }\end{array}$ & ${ }^{\circ} \mathrm{C}$ & 81.297 & 74.644 & 28.563 & 28.528 & 26.922 \\
\hline $\begin{array}{l}\text { Condenser inlet water } \\
\text { pressure }\end{array}$ & $\mathrm{kPa}$ & 0.5873 & 0.5882 & 0.2666 & 0.2536 & 0.2602 \\
\hline $\begin{array}{l}\text { Condenser outlet water } \\
\text { pressure }\end{array}$ & $\mathrm{kPa}$ & 0.5582 & 0.5597 & 0.0896 & 0.0862 & 0.0893 \\
\hline $\begin{array}{l}\text { Condenser hot well water } \\
\text { temperature }\end{array}$ & ${ }^{\circ} \mathrm{C}$ & 81.818 & 75.732 & 33.288 & 32.624 & 30.323 \\
\hline Condenser pressure & $\mathrm{kPa}$ & 54.949 & 40.871 & 4.647 & 4.52 & 4.129 \\
\hline $\begin{array}{l}\text { Cooling water temperature } \\
\text { rise }\end{array}$ & ${ }^{\circ} \mathrm{C}$ & 29.442 & 26.558 & 9.408 & 8.451 & 6.399 \\
\hline $\begin{array}{l}\text { Super-cooling degree of } \\
\text { condensation water }\end{array}$ & ${ }^{\circ} \mathrm{C}$ & 1.896 & 0.672 & -1.688 & -1.512 & -0.791 \\
\hline $\begin{array}{l}\text { Heat transfer terminal } \\
\text { temperature difference }\end{array}$ & ${ }^{\circ} \mathrm{C}$ & 2.417 & 1.76 & 3.037 & 2.584 & 2.61 \\
\hline $\begin{array}{l}\text { Logarithmic mean } \\
\text { temperature difference }\end{array}$ & ${ }^{\circ} \mathrm{C}$ & 11.417 & 9.559 & 6.670 & 5.821 & 5.165 \\
\hline Condenser thermal load & $\mathrm{MJ} / \mathrm{h}$ & 1377658.9 & 1083923.2 & 1547437.2 & 1357787.0 & 1040635.6 \\
\hline $\begin{array}{l}\text { Circulating cooling water } \\
\text { flow }\end{array}$ & $\mathrm{t} / \mathrm{h}$ & 11194.33 & 9763.98 & 41746.445 & 40778.132 & 41275.31 \\
\hline $\begin{array}{l}\text { Experimental overall heat } \\
\text { transfer coefficient Kt }\end{array}$ & $\mathrm{kW} /\left(\mathrm{m}^{2} .{ }^{\circ} \mathrm{C}\right)$ & 1.9375 & 1.8206 & 3.7251 & 3.7453 & 3.2351 \\
\hline Experimental flow rate & $\mathrm{m} / \mathrm{s}$ & 0.706 & 0.614 & 2.517 & 2.458 & 2.488 \\
\hline $\begin{array}{l}\text { Modified overall heat } \\
\text { transfer coefficient Kc }\end{array}$ & $\mathrm{kW} /\left(\mathrm{m}^{2} .{ }^{\circ} \mathrm{C}\right)$ & 1.805 & 1.8223 & 3.5445 & 3.5649 & 3.0483 \\
\hline $\begin{array}{l}\text { Cooling water outlet } \\
\text { temperature after the } \\
\text { correction of the inlet water } \\
\text { temperature }\end{array}$ & ${ }^{\circ} \mathrm{C}$ & 82.442 & 79.558 & 29.408 & 28.451 & 26.399 \\
\hline $\begin{array}{l}\text { Logarithmic mean } \\
\text { temperature difference } \\
\text { coefficient after correction } \\
\text { of the overall heat transfer } \\
\text { coefficient }\end{array}$ & $\longrightarrow$ & 2.4024 & 2.781 & 1.342 & 1.382 & 1.167 \\
\hline $\begin{array}{l}\text { Circulating water } \\
\text { temperature rise after } \\
\text { correction of design flow }\end{array}$ & ${ }^{\circ} \mathrm{C}$ & 33.978 & 26.733 & 10.615 & 9.314 & 7.138 \\
\hline $\begin{array}{l}\text { Modified cooling water } \\
\text { outlet temperature }\end{array}$ & ${ }^{\circ} \mathrm{C}$ & 86.979 & 79.733 & 30.615 & 29.314 & 27.138 \\
\hline $\begin{array}{ll}\begin{array}{l}\text { Modified } \\
\text { temperature of } \\
\text { pressure }\end{array} & \begin{array}{l}\text { saturation } \\
\text { condenser }\end{array} \\
\end{array}$ & ${ }^{\circ} \mathrm{C}$ & 85.372 & 81.313 & 32.736 & 31.284 & 29.291 \\
\hline $\begin{array}{lrr}\text { Corrected } & \text { heat transfer } \\
\text { terminal } & \text { temperature } \\
\text { difference } & \\
\end{array}$ & ${ }^{\circ} \mathrm{C}$ & 1.607 & 1.58 & 2.121 & 1.97 & 2.153 \\
\hline $\begin{array}{l}\text { Corrected } \\
\text { pressure }\end{array}$ & $\mathrm{kPa}$ & 58.653 & 49.936 & 4.955 & 4.564 & 4.072 \\
\hline Condenser water resistance & $\mathrm{kPa}$ & 29.1 & 28.5 & 177.0 & 167.4 & 170.9 \\
\hline $\begin{array}{lll}\begin{array}{l}\text { Water resistance } \\
\text { circulating after } \\
\text { correction }\end{array} & & \\
\end{array}$ & $\mathrm{kPa}$ & 22.5 & 28.2 & 142.4 & 140.5 & 140.4 \\
\hline
\end{tabular}


It can be seen from the high and low backpressure test results that after the condenser transformation, under normal backpressure and test generator power of 319MW condition with two circulating pump running at high speed, the condenser running pressure is $4.647 \mathrm{kPa}$, the condenser corrected pressure modified by circulating water flow rate and inlet temperature is $4.955 \mathrm{kPa}$ slightly higher than the design value,the corrected maximum terminal temperature difference is $2.15^{\circ} \mathrm{C}$. By the condensation water super cooling degree is greater, at high backpressure of $230432 \mathrm{~kW}$, the maximum super cooling degree of condensation water is $1.896^{\circ} \mathrm{C}$, which is higher than the design value.

The maximum unit generating capacity can be $230432 \mathrm{~kW}$ in the high backpressure heating conditions with similar main stream flow rate. By this time, the circulating water temperature rise is $29.442^{\circ} \mathrm{C}$, the condensation water super cooling degree is $1.896^{\circ} \mathrm{C}$, the condenser heat transfer terminal temperature difference is $2.417^{\circ} \mathrm{C}$, the condenser pressure is $54.949 \mathrm{kPa}$. Corrected by circulating water inlet temperature and influent flow rate, the circulating water temperature rise is $33.978^{\circ} \mathrm{C}$, the condenser heat transfer terminal temperature difference is $1.607^{\circ} \mathrm{C}$, and the condenser pressure is $58.653 \mathrm{kPa}$. When the unit operates at normal backpressure conditions, the generator power is $269718 \mathrm{~kW}$, the circulating water temperature rise is $8.451^{\circ} \mathrm{C}$, the condensation water super cooling degree is $1.688^{\circ} \mathrm{C}$, the condenser heat transfer terminal temperature difference is $3.037^{\circ} \mathrm{C}$, and the condenser pressure is $4.52 \mathrm{kPa}$. The circulating water temperature rise modified by circulating water flow rate and inlet temperature is $9.314^{\circ} \mathrm{C}$, the condenser heat transfer terminal temperature difference is $197^{\circ} \mathrm{C}$, and the condenser pressure is $4.564 \mathrm{kPa}$.

\section{THE OPERATIONAL TEST RESULTS ANALYSIS OF HIGH AND LOW BACKPRESSURE AFTER CONDENSER TRANSFORMATION}

Analyze the experimental data of high and low backpressure operation and comparison with the design value. Under corresponding condition, the difference between circulating water flow and the design value is small. So the circulating water flow rate in the circulating water pipe is approximately the same as the design value. The condenser terminal temperature difference at high backpressure heating condition is small, the maximum is $2.417^{\circ} \mathrm{C}$, the condenser terminal temperature difference modified by circulating water flow rate and inlet temperature is $1.607^{\circ} \mathrm{C}$. Under 3 low backpressure conditions, the condenser terminal differences are $3.037^{\circ} \mathrm{C}$, $2.584^{\circ} \mathrm{C}$ and $2.61^{\circ} \mathrm{C}$ respectively. After the correction of circulating water flow and inlet water temperature, the condenser terminal differences are $2.121^{\circ} \mathrm{C}, 1.97^{\circ} \mathrm{C}$ and $2.153^{\circ} \mathrm{C}$ respectively. The condenser test terminal temperature difference and the correction terminal temperature difference are all lower than the design value $4^{\circ} \mathrm{C}$. After the condenser transformation, the high and low backpressure safe and economical operation requirements can be met.

\section{A. The Influence of Unit Operating Conditions on Condenser Performance}

When the steam turbine operates at high backpressure condition in heating period, the condenser circulating water system switch to the hot water circulating water loop set up by circulation pump, a new "heat-water" exchange system formed. After the switch completed, the water flow to the condenser is reduced to $7400 \sim 9700 \mathrm{t} / \mathrm{h}$, and the backpressure of the condenser is raised from $4.9 \mathrm{kPa}$ to $54 \mathrm{kPa}$, and the low-pressure cylinder exhaust steam temperature is raised from $30 \sim 45^{\circ} \mathrm{C}$ to $83^{\circ} \mathrm{C}$. After the first heating of the condenser, the heating network circulating water temperature is raised from $53^{\circ} \mathrm{C}$ up to $80^{\circ} \mathrm{C}$, and then is transported to the first heating network heater after boosted by the heating network pump, the heating network water is reheated to supply the heat-supply network.

Compare the condenser design data and test results of high and low backpressure situations, when the unit operating at high backpressure heating condition, the circulating water flow is low, the circulating water flow rate in the heat transfer tube is low also, which may affect on the accuracy of the condenser heat transfer calculation model, and also on the calculated results and the condenser actual heat transfer ability. When steam turbine and condenser are carried out high backpressure heating transformation, the relationship among the heat load, the circulation water flow and the condenser backpressure should be considered to make the steam turbine and condenser running in optimal state.

Take analysis on the data shown before, under the high backpressure of $230 \mathrm{MW}$ load, the condenser backpressure is $54.95 \mathrm{kPa}$, the circulating water flow is $11194 \mathrm{t} / \mathrm{h}$, the circulating water flow rate in the heat transfer tube is $0.706 \mathrm{~m} / \mathrm{s}$, the circulating water flow is greater than design value, the circulating water temperature is less than the design value, hence reduces the condenser high pressure heating capacity and thermal efficiency of the unit. When the unit operating in high pressure heating period, the low-pressure cylinder communication pipe steam extraction should be reduced or stopped according to the heat load requirements to optimize the circulating water and the condenser pressure, meet the heat load requirements using high pressure heating and increase power generation capacity, reduce the circulating water flow and auxiliary power rate. Under the normal backpressure condition with two circulating pump running at high speed, the circulating water flow is $41000 \mathrm{t} / \mathrm{h}$. At $319 \mathrm{MW}$ situation, the condenser test terminal temperature difference and correction terminal temperature difference are $3.037^{\circ} \mathrm{C}$ and $2.121^{\circ} \mathrm{C}$ respectively. In situations with similar main steam flow corresponding to high backpressure situation at $230 \mathrm{MW}$ load, the unit power generation is $270 \mathrm{MW}$, the condenser test terminal temperature difference and correction terminal temperature difference are $2.584^{\circ} \mathrm{C}$ and $1.97^{\circ} \mathrm{C}$ respectively.

Analyze the data that the temperature rise and the condenser terminal temperature difference all reach the design value, the condenser operates well, the condenser can achieve high or low backpressure operation with the 
circulating water system switch.

\section{B. The Condenser Performance Comparison before and after Retrofit}

After the high backpressure heat supply retrofit, the condenser operates under high backpressure in heating seasons and low backpressure in non-heating seasons, that the low-pressure cylinder exhaust steam temperature, the pressure on both the steam side and water side changed greatly. The condenser high backpressure retrofit can accommodate great changes between two backpressure conditions, at the meantime the condenser tube bundle layout should be optimized to improve the condenser performance and the economy of the steam turbine. The comparison of the experimental results under low backpressure condition before and after modification is listed in Table 4.

TABLE 4. TEST RESULTS OF 300MW UNIT UNDER LOW BACKPRESSURE THAT BEFORE AND AFTER RETROFIT

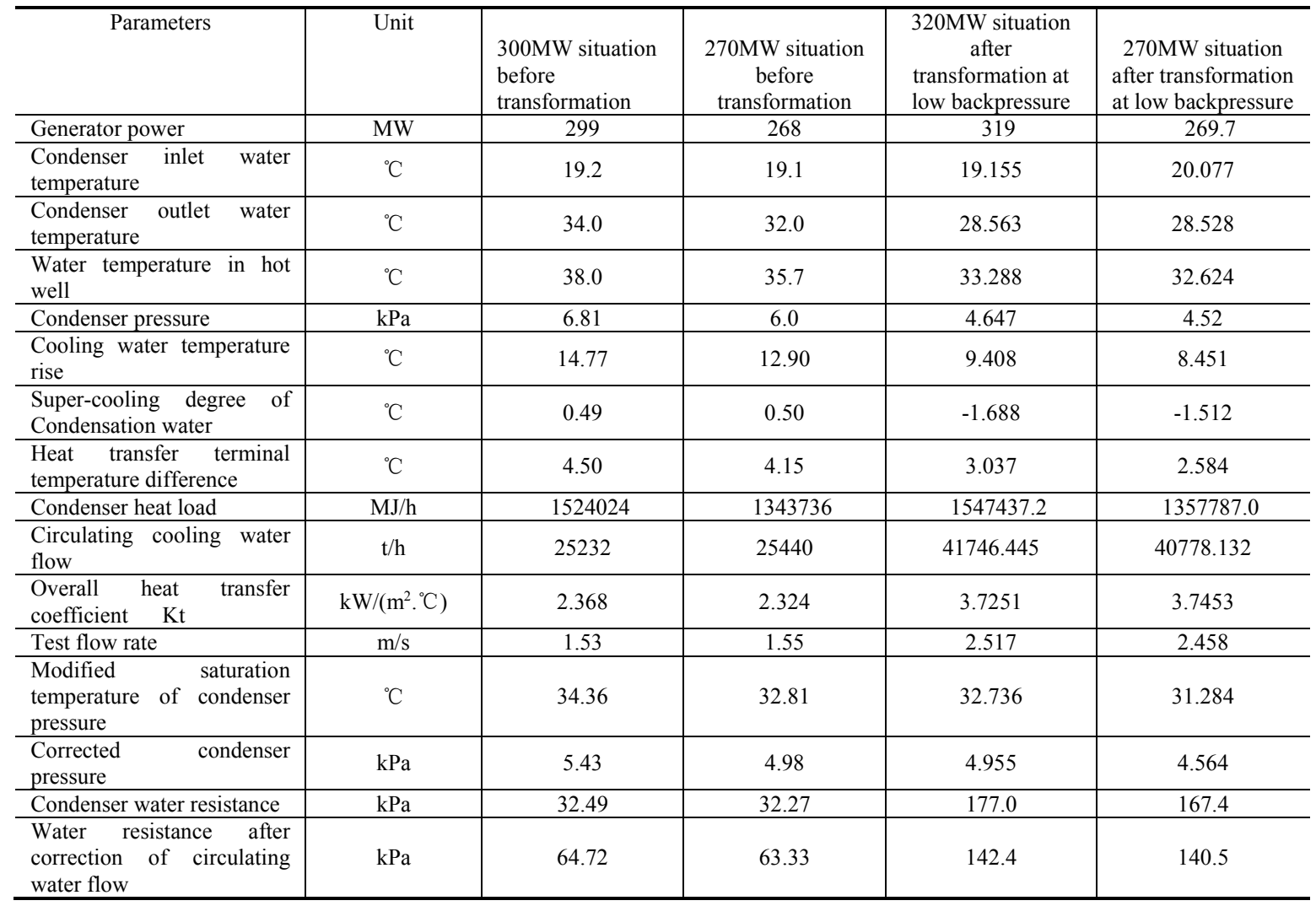

From the Table 4 we can found that the condenser pressure at $320 \mathrm{MW}$ condition after retrofit reduces $0.475 \mathrm{kPa}$ than that at $300 \mathrm{MW}$ condition before retrofit, the condenser pressure after transformation reduced $0.416 \mathrm{kPa}$ than that before the transformation at similar $270 \mathrm{MW}$ situation. After the retrofit, the condenser performance basically reaches its design value and has a great improvement.

\section{CONCLUSION}

For the high backpressure heat supply retrofit of the 300MW unit, the condenser operates under high backpressure in heating seasons and low backpressure in non-heating seasons, the condenser operating condition changed greatly. In order to meet the high and low backpressure's safety and economical operation requirements, the condenser strengthening retrofit is conducted. This paper discusses the technology and content of the condenser retrofit, and the performance of the condenser that before and after retrofit is tested to verify the change of the performance index. When the circulating water flow rate is close to the design value, the condenser terminal temperature difference is small regardless of the condenser operates under high or low backpressure condition. The condenser average terminal temperature difference is $2.09^{\circ} \mathrm{C}$ when it operates under high backpressure condition, the condenser average terminal temperature difference is $2.77^{\circ} \mathrm{C}$ when it operates under low backpressure condition, both less than the design terminal temperature difference. After the retrofit, under the normal pressure condition of $319 \mathrm{MW}$ load, the condenser operation pressure is $4.647 \mathrm{kPa}$, the correction condenser pressure modified by the circulating water flow rate and the inlet temperature is $4.955 \mathrm{kPa}$, the maximum correction terminal 
temperature difference is $2.15^{\circ} \mathrm{C}$, the condenser pressure is higher than the design value.

It can be found by the test result of before and after the condenser retrofit, the condenser performance is improved obviously after the high backpressure retrofit. The condenser pressure after the retrofit under $320 \mathrm{MW}$ condition is reduced by $0.475 \mathrm{kPa}$ than that $300 \mathrm{MW}$ condition before the retrofit. Under the similar 270MW load condition, the condenser pressure is reduced by $0.416 \mathrm{kPa}$ than that before the retrofit.

\section{REFERENCE}

[1] Kao Fang. Analysis of Circulating Water Heat Supply Reformation in an Unit on Low Vacuum of Small Condensing Steam Turbine[J].Shandong Electric Power, 2010,3:46-48.

[2] Fang Min, Cong Lu. Application and economic benefit analysis for the first stage of circulating water heating technology in Yinchuan thermal power plant $[J]$. Journa 1 of Shenyang Institute of Engineering (Natural Science), 2010,vol6(1):10-12.

[3] Zhang Xiukun, Zheng Gang, Liu Chuanwei,et al. The Analysis and Application of Low Vacuum Circulating Water Heating Technology of Condensate Pumping Unit[J]. Journal of Shanghai University of Electric Power, 2009,vol25(6):543-546.

[4] Zheng Jie. Application of Circulating Water Heat Supply Technology in an Unit on Low Vaccum Running[J]. Energy Conservation Technology, Jul.2006,No.4:380-382. 